Emiliana Eusebio-Ponce ${ }^{1,2}$ Francisco Javier Candel $\left.\right|^{2,3}$ Robert Paulino-Ramirez ${ }^{1}$ Irene Serrano-García ${ }^{4}$ Eduardo Anguita2,5

\section{Seroprevalence and Trends of HTLV-1/2 among Blood Donors of Santo Domingo, Dominican Republic, 2012-2017}

\author{
Instituto de Medicina Tropical \& Salud Global, Universidad Iberoamericana (UNIBE), Los Rios, Santo Domingo, Domini- \\ can Republic. \\ 2Department of Medicine, Medical School, Universidad Complutense de Madrid (UCM). Madrid, Spain. \\ ${ }^{3}$ Clinical Microbiology and Infectious Diseases Department, Hospital Clínico San Carlos, IML, IdISSC. Madrid, Spain. \\ ${ }^{4}$ Research methodology unit, Hospital Clinico San Carlos, IdISSC Madrid, Spain. \\ ${ }^{5}$ Hematology Department, Hospital Clínico San Carlos, IML, IdISSC. Madrid, Spain.
}

Article history

Received: 6 October 2020; Revision Requested: 28 0ctober 2020; Revision Received: 9 November 2020; Accepted: 13 November 2020; Published: 11 December 2020

\begin{abstract}
Objectives. Being a Caribbean country, the Dominican Republic is considered endemic for HTLV-1. Viral screening in blood banks is recommended for this blood borne infection. The purpose of this work is to analyze the seroprevalence and trends of HTLV-1/2 in the Dominican Republic blood donors; it is focused on Santo Domingo, the capital of the country, which has the largest blood donation activity. We also aim at comparing our findings with published data from neighboring countries.
\end{abstract}

Patients and methods. We performed a retrospective cross-sectional study of 10 blood centers of Santo Domingo, which reported HTLV and the other blood-transmitted infections in full. They represent more than $40 \%$ of the province's blood donations. Annual seroprevalence of HTLV-1/2, period prevalence (2012-2017), and time trend were determined.

Results. A total of 352,960 blood donations were evaluated. The HTLV-1/2 period prevalence was 0.26\% $(929 / 352,960)$ (95\% Cl: $0.24-0.28 \%$ ). We also found a marked predominance of replacement donation (90.4\%) in comparison to voluntary contributions (9.6\%). Therefore, this blood donor study may provide clues on the general prevalence of the infection.

Conclusions. Seroprevalence of HTLV-1/2 in blood donors of Santo Domingo, Dominican Republic, showed a relatively low and steady trend in the studied period.

Keywords: HTLV-1, Dominican Republic, blood donors, prevalence, Santo Domingo

Correspondence:

Eduardo Anguita

Hematology Department, Hospital Clinico San Carlos, IML, IdISSC. Medicine, UCM.

Profesor Martin Lagos s/n, 28040 Madrid, Spain.

Phone: + 34913303321

Fax: + 34913303322

E-mail:eduardo.anguita@salud.madrid.org

\section{Seroprevalencia y tendencias de HTLV-1/2 en los donantes de sangre de Santo Domingo, República Dominicana, 2012-2017}

\section{RESUMEN}

Objetivo. Como país caribeño, la República Dominicana es considerada endémica para HTLV-1. El propósito de este trabajo es analizar la seroprevalencia y la tendencia del HTLV-1/2 en donantes de Santo Domingo, que al ser la capital concentra la mayoría de las donaciones. También pretendemos comparar nuestros hallazgos con los datos de los países vecinos.

Pacientes y métodos. Hemos realizado un estudio transversal retrospectivo de los 10 centros de transfusión de Santo Domingo que comunicaron la detección de HTLV y las otras infecciones de transmisión sanguínea en su totalidad, que representan más del $40 \%$ de las donaciones de la provincia. Se determinó la seroprevalencia anual de HTLV-1/2, la prevalencia del periodo (2012-2017) y la tendencia temporal.

Resultados. Se evaluaron un total de 352.960 donaciones. La prevalencia de HTLV-1/2 en el período estudiado fue del 0,26\% (929/352.960) (IC del 95\%: 0,24-0,28\%). Encontramos un marcado predominio de la donación de reemplazo en comparación con la voluntaria. Por lo tanto, este estudio puede proporcionar claves sobre la prevalencia general de la infección.

Conclusiones. La seroprevalencia de HTLV-1/2 en donantes de sangre de Santo Domingo, República Dominicana, ha sido relativamente baja y estable en el periodo estudiado.

Palabras clave: HTLV-1, República Dominicana, donantes de sangre, prevalencia, Santo Domingo 


\section{INTRODUCTION}

Human Lymphotropic Virus (HTLV) is a complex deltaretrovirus that belongs to the Retroviridae family [1]. It has four known strains named HTLV-1, HTLV-2, HTLV-3 and HTLV-4. HTLV-1 is the most pathogenic one for humans, and it is primarily associated with Adult T cell Leukemia/Lymphoma (ATLL) and HTLV-1-Associated Myelopathy/Tropical Spastic Paraparesis (HAM/TSP) [2]. HTLV-2 is rarely pathogenic, and it is only sporadically associated with neurological disorders [2].

HTLV-1 was first identified in 1979, when researchers from the Bethesda National Cancer Institute isolated the virus in a sample of Cutaneous T Lymphoma, later identified as ATLL. This was the first time that a link between a retrovirus and a human neoplasm was established [3].

HTLV-1 transmission routes may be vertical (mainly through breastfeeding), sexual or parenteral [4]. It is estimated that this virus affects at least 10 million people worldwide, producing pathologies in approximately $5 \%$ of the infected individuals. The main endemic regions for HTLV-1 are southwest Japan, Sub-Saharan Africa, Melanesia, South America, and the Caribbean [5].

Difficult access to the general population of specific areas and the non-homogeneous distribution of the virus makes it difficult to perform representative epidemiological studies. Therefore, information from selected populations, such as blood donors, is generally useful, since it grants access to large numbers of infected individuals, many of them asymptomatic. Furthermore, it allows us to break the chain of infection and to establish prevention strategies to avoid both the virus and its associated diseases.

Likelihood of HTLV-1 seroconversion after injection of contaminated blood products is approximately 40-60\% [6]. Thus, the risk of transmission through asymptomatic blood donors should be considered, particularly in high prevalence areas. Therefore, it is crucial to validate the screening of donations for HTLV-1/2 with local epidemiological evidence [7].

The proportion of the different types of donors (voluntary/replacement) is different depending on the policies of each country. In some countries, donors are usually replacement donors, mainly family members or friends of hospitalized patients; sometimes, donors are illegally paid to give blood. Thus, epidemiological and demographic characteristics vary among blood donors. They can be entirely representative of the middle-class population in some countries, while in other areas, they may represent low socioeconomic populations [5]. In the Dominican Republic, where we have focused our study, blood donations are mainly made by replacement, with a wide socioeconomic and cultural diversity among these blood donors [8].

As a Caribbean country, the Dominican Republic has an estimated prevalence of HTLV-1 infection ranging from 1 to $5 \%$ [5]. Nonetheless, there are very few studies in this particular country, most of them focused on risk groups [9-11]. Therefore, new and specific studies are needed to estimate the infection more accurately.

The presence of HTLV-1/2 in blood donors of Santo Domingo was first detected in 1987, when Koenig et al. conducted a prevalence study in different populations of the Dominican Republic [9]. A total of 1955 healthy blood donors were evaluated at a National Laboratory, showing a 1.2\% seroprevalence. These authors suggested that the country could have an overall incidence of 200-400 newly infected individuals each year. Still, the cost of blood screening and the fact that the majority (98-99\%) of HTLV-infected individuals never developed symptoms made a screening program untenable [9].

More recently, Paulino-Ramirez et al. performed a study in which they collected and analyzed plasma from 200 participants co-infected with Human Immunodeficiency Virus (HIV); they were transactional sex workers and intravenous drug users of Santo Domingo and they presented an overall weighted seroprevalence of HTLV-1/2 lgG antibodies of 13.91\% in men and $10.59 \%$ in women [11].

HTLV-1/2 has been screened in some blood banks of the Dominican Republic since 2005, but it was not until 2009 that it was fully implemented [8]. There are 63 blood banks in the country, half of which belong to the Ministry of Public Health. The private and military sectors manage the rest of the centers. In mid-2019, a National Hemocenter seeking to address the blood deficiency and raise the donation capacity of the Dominican Republic, was put into service [12].

It is particularly important to evaluate hemovigilance policies to ensure transfusion safety. The development of epidemiological studies is a valuable tool to achieve this purpose. This study aims at obtaining recent data on seroprevalence and trends of HTLV-1/2 in blood banks of Santo Domingo, Dominican Republic.

\section{METHODS}

Study design and population. We performed a retrospective cross-sectional study based on data obtained from the National Directory of Blood Banks (Public Health Ministry) of Santo Domingo, Dominican Republic. This included data collected from 10 transfusion centers of Santo Domingo (Dominican Red Cross, Salvador B. Gautier Hospital, Padre Billini Hospital, La Altagracia Maternity Hospital, Robert Read Cabral Child Hospital, Blood and Specialties Center, Dominican Medical Center, CEDIMAT, Referencia Clinical Laboratory, and Marcelino Velez Santana Hospital) during the 2012-2017 period.

Participants were blood donors that met the criteria established by the Ministry of Public Health in the Dominican Republic: aged between 18 and 65 years, or older than 16 years with parental consent; minimum weight of 110 pounds; no previous history of HIV, HBV, HVC, tuberculosis or organ transplant; no severe diseases or conditions such as cancer, heart failure or other severe chronic diseases; no current pregnancy or breastfeeding; no history of tattoos, piercings or acupuncture in the last 12 months; no consumption of alcoholic bever- 


\begin{tabular}{|c|c|c|c|c|c|}
\hline Table & \multicolumn{5}{|c|}{$\begin{array}{l}\text { HTLV I/II Seroprevalence of period 2012-2017 and type of donation } \\
\text { (voluntary and replacement) in Santo Domingo }\end{array}$} \\
\hline \multirow[t]{2}{*}{ Year } & \multicolumn{3}{|c|}{ HTLV I/II } & \multicolumn{2}{|c|}{ Donation } \\
\hline & Screened Samples & Positive samples & Seroprevalence & Voluntary $(\%)$ & Replacement (\%) \\
\hline 2012 & 51,593 & 154 & $0.30 \%$ & $7,634(17 \%)$ & $43,914(86 \%)$ \\
\hline 2013 & 54,510 & 163 & $0.30 \%$ & $6,157(13 \%)$ & $47,643(87 \%)$ \\
\hline 2014 & 56,155 & 99 & $0.18 \%$ & $4,993(10 \%)$ & $51,288(90 \%)$ \\
\hline 2015 & 57,059 & 123 & $0.21 \%$ & $5,348(10 \%)$ & $52,393(90 \%)$ \\
\hline 2016 & 67,294 & 148 & $0.22 \%$ & 4,332 (7\%) & $62,941(93 \%)$ \\
\hline 2017 & 66,349 & 242 & $0.36 \%$ & $5,537(9 \%)$ & $60,880(91 \%)$ \\
\hline
\end{tabular}

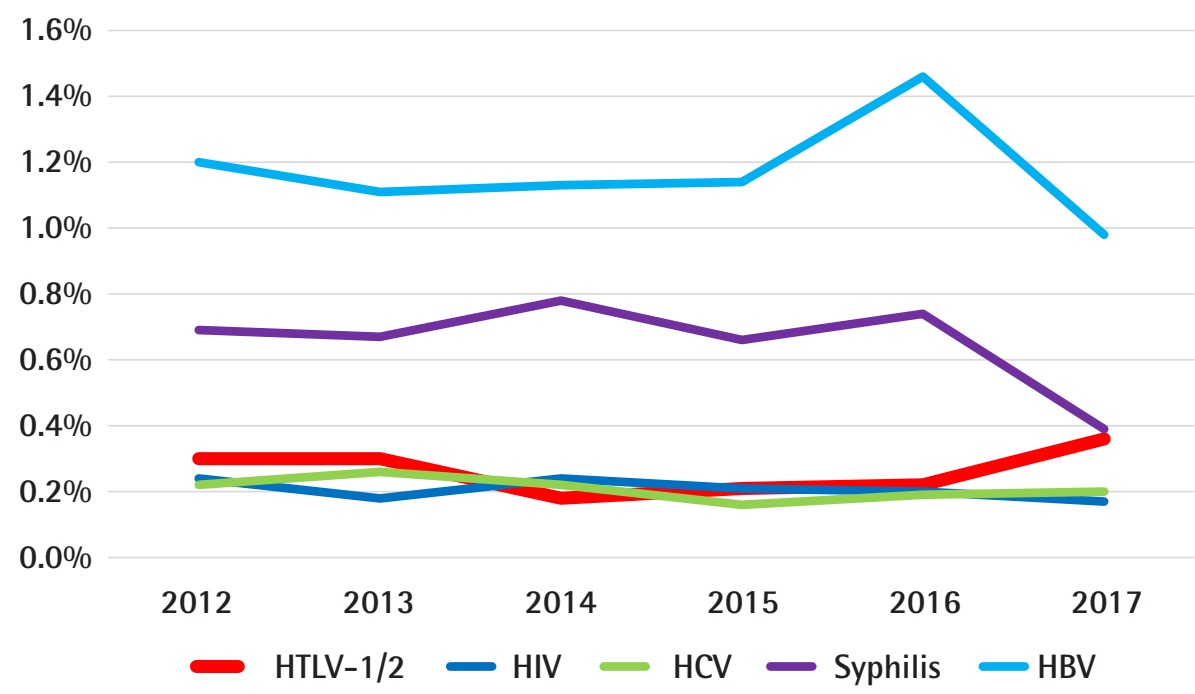

Figure 1 Seroprevalence and trends of HTLV-1/2 and other blood borne infections (HIV, HCV, HBV and syphilis) during 2012-2017 period in blood banks of Santo Domingo, Dominican Republic. Here, detection of HTLV-1/2 is shown in the context of other common blood transmitted microorganisms; so its relative impact and variation can be compared.

ages in the last 24 hours and not having undergone any major surgery in the last six months before donating blood [13].

The minimum sample size was estimated with a sample proportion of 50\% following the formula used for qualitative variables of cross-sectional studies [14].

Detection tests. The serological tests were Enzyme-Linked Immunosorbent Assay (ELISA) and Chemiluminescence Immunoassay (CLIA).

Statistical analysis. Annual seroprevalence of HTLV-1/2 HIV, Hepatitis C Virus (HCV), Hepatitis B Virus (HBV) and syphilis, period prevalence (2012-2017), and time trend were deter- mined. For this purpose, we used a time series analysis adjusted to a first-order moving average model. We also performed the least-squares method to estimate the secular trend. Statistical analyses were performed using $\mathrm{R}$ and Graphpad softwares.

Ethics. The present research was approved by UNIBE's institutional review board and ethics committee (reference CEI-2019-03)

\section{RESULTS}

In Santo Domingo 25 blood banks use to report their data annually. Nonetheless, for the period 2012-2017, only 10 of them communicated their results fully. We selected these ten 


\begin{tabular}{|c|c|c|c|c|c|}
\hline \multirow{3}{*}{$\begin{array}{l}\text { Table } 2 \\
\text { Year }\end{array}$} & \multicolumn{5}{|c|}{$\begin{array}{l}\text { Seroprevalence of HIV (Human Immunodeficiency Virus), HCV (Hepatitis C } \\
\text { Virus), HBV (Hepatitis B Virus) and Syphilis in the period 2012-2017 }\end{array}$} \\
\hline & \multicolumn{4}{|c|}{ Positive samples (seroprevalence) } & \multirow[t]{2}{*}{ Screened Samples } \\
\hline & HIV & $\mathrm{HCV}$ & HBV & Syphilis & \\
\hline 2012 & $125(0.24 \%)$ & $116(0.22 \%)$ & $621(1.20 \%)$ & $354(0.69 \%)$ & 51,593 \\
\hline 2013 & $101(0.18 \%)$ & $140(0.26 \%)$ & $596(1.11 \%)$ & $368(0.67 \%)$ & 54,510 \\
\hline 2014 & $135(0.24 \%)$ & $125(0.22 \%)$ & $720(1.13 \%)$ & $437(0.78 \%)$ & 56,155 \\
\hline 2015 & $118(0.21 \%)$ & $92(0.16 \%)$ & $652(1.14 \%)$ & $379(0.66 \%)$ & 57,023 \\
\hline 2016 & $136(0.20 \%)$ & $128(0.19 \%)$ & $985(1.46 \%)$ & $498(0.74 \%)$ & 67,294 \\
\hline 2017 & $110(0.17 \%)$ & $129(0.20 \%)$ & $649(0.98 \%)$ & $260(0.39 \%)$ & 65,685 \\
\hline
\end{tabular}

centers to analyze the HTLV-1/2, HIV, HCV, HBV and syphilis prevalence and trend for this period, thus avoiding incomplete information that could introduce a bias in our study. All of them are located in Santo Domingo city and represent more than $40 \%$ of the province's blood donations.

A total of 352,960 blood donations were evaluated by ELISA or CLIA (Table 1 and Figure 1).

HTLV-1/2 period prevalence was 0.26\% $(929 / 352,960)$ (95\% Cl: 0.24-0.28\%). Overall HTLV-1/2 prevalence was 263 per 100,000 donations during the six years.

Annual HTLV-1/2 prevalence was $0.30 \%$ in 2012, $0.30 \%$ in 2013,0.18\% in 2014, 0.21\% in 2015, 0.22\% in 2016 and $0.36 \%$ in 2017, indicating that there was no significant secular trend during the 2012-2017 period ( $p$ for trend=0.5596).

Seroprevalence and trends of HIV, HCV, HBV and syphilis in the period 2012-2017 are shown in Figure 1 and Table 2.

The type of donation (voluntary and replacement) was studied. As detailed in Table 1, voluntary donations represented 9.6\% $(34,001 / 353,060)$ and replacement donation 90.4\% $(319,059 / 353,060)$.

\section{DISCUSSION}

We have analyzed seroprevalence and trends of HTLV-1/2 in blood banks of the capital city of the Dominican Republic, Santo Domingo. Most studies on HTLV-1 have been performed in Japan; other areas, like the Caribbean countries, are globally considered without understanding the substantial differences between them. Being a Caribbean country, the Dominican Republic is deemed endemic for HTLV-1. Nonetheless, there are very few epidemiological data about this virus, even though HTLV-1/2 has been fully screened in Dominican blood banks since 2009.

For the present study, we selected ten blood banks of Santo Domingo city, which collected most of the city's blood donations and studied them for the period 2012-2017. We show here a period prevalence of $0.26 \%$ of HTLV-1/2 among blood donors. The trend of HTLV seroprevalence in the studied period (2012-2017) seems to be low and steady, like the other blood-borne diseases reported in the same period. Also, it showed similar data to those reported by the Ministry of Public Health for blood donors of the Dominican Republic in the period 2005-2011 [8]. However, by the time the first HTLV study on Dominican blood donors took place in 1987 seroprevalence was $1.2 \%$. Since the implementation of a HTLV-1/2 blood unit screening in 2005, a lower prevalence has been shown, probably due to recent improvements in donor selection and blood donation policies [8].

Latin America and the Caribbean cannot be considered as a homogeneous region. Each country has different blood donation models (voluntary, replacement, non-remunerated, remunerated) and ethnic background. Several studies performed on large populations of blood donors have found differences in seroprevalence depending on the geographical location and ethnic origin of the donors $[5,15]$. Most inhabitants of the Caribbean region are of African ancestry; in fact, HTLV-1 prevalence has been found to be higher in areas populated with inhabitants of African descent in comparison with those inhabited by people of mixed and white descent. This is the case of Brazil, where the prevalence of HTLV-1/2 in blood donors is heterogeneous, ranging from 0.04 to $1 \%[5,16-22]$ and a large study on Brazilian blood donors showed that regional differences in HTLV-1 prevalence are probably due to the ethnic origin of the underlying population. A higher prevalence in colored donors $(2.14 / 1,000)$, versus mixed-race donors $(1.58 / 1,000)$, or white donors $(0.79 / 1,000)$ was shown $[5,15]$. In Peru, very few studies on HTLV-1 have been done in blood donors, showing a prevalence of around 0.9\% [23]. Colombia shows a seroprevalence of HTLV-1/2 in the population of blood donors in Cali and Medellin of $0.24 \%$ and $0.176 \%-0.06 \%$, respectively [24-26]. Also, a retrospective study analyzing screening and positivity for HTLV-1 and 2 data collected from 2001 to 2014 by Colombian blood banks, showed a cumulative reactivity of $0.30 \%$ [27]. Chile and Argentina, with a population of predominantly European origin, seem to have a low and exceptionally low seroprevalence of HTLV-1 of $0.10 \%$ and $0.011 \%$ respectively $[28,29]$. Paraguay shows a prevalence of $0.37 \%$ according to the available information[30]. 
There is not much information available on Central America, but some studies indicate a seroprevalence of HTLV up to $0.14 \%$ in Honduras and $0.22 \%$ in Costa Rica $[31,32]$.

Other studies on blood donors of the Caribbean region also suggest a higher prevalence in countries where people are of predominantly Black descent, such as Jamaica, where studies show a prevalence of 2.5\% $(376 / 15,022)$ and 3.8\% (30/794) $[33,34]$. These dynamics are less evident in Haiti, where according to the 2015 report of the Panamerican Health Association there were $0.78 \%(216 / 27,752)$ positive blood units; and in the French West Indies (Martinique and Guadeloupe), where HTLV-1 seroprevalence in blood donors is around 0.4-0.3\% $[35,36]$. On the contrary, in countries like Cuba, where there are relatively few African ancestry persons compared with the previously mentioned countries, there is a very low prevalence of HTLV in blood donors of $0.01 \%(3 / 16,920)$ [37]. Consistently, Puerto Rico seems to have a low HTLV prevalence: around $0.25 \%(1 / 400)$ [38]. This rate is similar to the one we found in Santo Domingo, as could be expected due to their common historical and ethnographic background and the likenesses in their populations, where mixed-race is predominant. Nonetheless, further studies are needed to confirm the absence of HTLV foci in certain areas that might lead to an increase in global prevalence among blood donors.

Despite, globally speaking, HTLV-1/2 seroprevalence in the Dominican Republic's blood donors seems to be low, the situation of the border provinces is not fully known, especially in remote areas where there are not even blood banks, not to speak of HTLV studies. Thus, additional studies focused on these provinces are needed; there, Haitian immigration is higher, something which could confirm the increase of viral transmission among this type of population.

Our findings of this study cannot be extrapolated to the general population, as blood donors are usually not representative -they are selected according to the blood safety protocols of each center and to country policies and so doing this could lead to bias and to an underestimation of HTLV prevalence. Thus, real HTLV prevalence among the general population of Santo Domingo and in the rest of the country could be higher than the one observed, especially if we consider that we limited the data analysis to the ten blood centers of Santo Domingo which fully reported their information on HTLV and the other blood-borne infections in the period studied.

Although these results may not be fully representative of the general population nor of the donor population of the entire country, they could well be a guidance of HTLV-1/2 seroprevalence and trend in blood donors of Santo Domingo and give a hint on the prevalence in the wider population. Blood donors use to belong to primarily low-risk populations. However, the predominance of replacement donation and the diversity of origins of the capital inhabitants allows this study to be more representative of the city population and supports the idea of a lower prevalence of HTLV-1 in the Hispanic Caribbean countries in comparison with other areas with a higher pro- portion of African ancestry population. However, studies on larger and broader populations are needed in order to confirm this hypothesis.

In the Dominican Republic, confirmatory testing of reactive donations is not performed in all blood centers. Ours is a study based on real-world diagnostic data with both the advantages and limitations of a work of this kind. The main drawback is the lack of confirmation of the results with other techniques in most of the centers and the absence of records of HTLV-1 and HTLV-2 discrimination in those performing western blot (WB) as confirmatory test. However, this also shows the need to improve blood bank procedures in Dominican Republic and probably in most of the HTLV endemic countries.

Tests commonly used for HTLV-1/2 confirmation and to differentiate between HTLV-1 and HTLV-2 infection are WB or innogenetics line immunoassay (INNO-LIA) and qualitative and/or quantitative polymerase chain reaction (PCR). Despite some improvements in the specificity of WB assays, indeterminate serological patterns are frequent and represent an important concern for routine screening and a major issue for comparative analyses between epidemiological studies $[5,39]$. INNO LIA, although is not so commonly used as WB, represents a good alternative, especially in co-infected patients, in which indeterminate result of WB could be an issue [40]. PCR is useful for the diagnosis and follow-up of HTLV-1 associated diseases such as ATLL and TSP/HAM. Moreover, it provides amplicons for sequencing analysis to determine the HTLV-1 genotype and generate molecular epidemiological data to better comprehend the evolutionary past of this virus [41]. However, this is a more expensive and complex test, thus it is not available in most blood centers of developing countries. We aim at validating and implementing this method for future studies in the Dominican Republic.

Notwithstanding the previous statements, it is essential to continue improving donor selection because a higher prevalence could be found in high-risk populations. Also, it is necessary to encourage voluntary blood donation, which nowadays represents only approximately a $20 \%$ of all blood donations in the Dominican Republic. This could improve blood safety and guarantee the blood supply of the country.

\section{FUNDING}

None to declare

\section{ACKNOWLEDGEMENTS}

We would like to thank the Blood Bank National Directory from the Dominican Public Health Ministry for providing us with the epidemiological data for this work and Fundación Hay Esperanza for support.

\section{CONFLICT OF INTEREST}

The authors have disclosed no conflicts of interest. 


\section{REFERENCES}

1. Giam C, Semmes O. HTLV-1 Infection and Adult T-Cell Leukemia/ Lymphoma-A Tale of Two Proteins: Tax and HBZ. Viruses. 2016; 8(6).pii:E161. doi: 10.3390/v8060161.

2. Mahieux R, Gessain A. HTLV-3/STLV-3 and HTLV-4 viruses: discovery, epidemiology, serology and molecular aspects. Viruses. 2011; 3(7):1074-90. doi:10.3390/v3071074

3. Poiesz BJ, Ruscetti FW, Gazdar AF, Bunn PA, Minna JD, Gallo RC. Detection and isolation of type $C$ retrovirus particles from fresh and cultured lymphocytes of a patient with cutaneous T-cell lymphoma. Proc Natl Acad Sci. 1980;77(12):7415-9. doi: 10.1073/ pnas.77.12.7415

4. Eusebio-Ponce E, Anguita E, Paulino-Ramirez R, Candel FJ. HTLV-1 infection: An emerging risk. Pathogenesis, epidemiology, diagnosis and associated diseases. Rev Esp Quimioter. 2019;32(6):485-96. PMID: 31648512

5. Gessain A, Cassar 0. Epidemiological Aspects and World Distribution of HTLV-1 Infection. Front Microbiol. 2012;3:388. doi: 10.3389/ fmicb.2012.00388.

6. Karimi G, Zadsar M, Pourfathollah AA. Seroprevalence and geographical distribution of human T-lymphotropic virus type 1 among volunteer blood donors in endemic areas of Iran. Virol J. 2017;14(1):14. doi:10.1186/s12985-017-0693-9

7. World Health Organization. Screening Donated Blood for Transfusion-Transmissible Infections: Recommendations. 2009. Available from: https://www.ncbi.nlm.nih.gov/books/NBK142989/

8. Ministerio de Salud Pública. Dirección Nacional de Bancos de Sangre. Política Nacional de Sangre. Santo Domingo, República Dominicana, 2014. ISBN: 978-9945-591-04-0

9. Koenig RE, Tolentino M, Taveras L, Ferro F, Zornoso C, Ferreiras J, et al. Prevalence of HTLV infection in the Dominican Republic: association with neurological disease. AIDS Res Hum Retroviruses. 1992;8(2):221-6. doi: 10.1089/aid.1992.8.221

10. Eusebio-Ponce E, Candel FJ, Anguita E. Human T-Cell Lymphotropic Virus Type 1 and associated diseases in Latin America. Trop Med Int Health. 2019;24(8):934-53. doi: 10.1111/tmi.13278.

11. Paulino-Ramirez R, Tapia L, Ruiz-Matuk C, Charow R, Budhwani $H$, Routy JP. T cell lymphotropic virus $1 / 2$ and human immunodeficiency virus antibodies identification among transactional sex workers and drug users in the Dominican Republic. Trans R Soc Trop Med Hyg. 2019;113(6):293-7. doi: 10.1093/trstmh/trz012

12. OPS (Organizacion Panamericana de la Salud) República Dominicana. El déficit de sangre en el país es de 188,522 unidades. 2009. Available from: https://www.paho.org/dor/index. php?option=com_content\&tview=articlectid=309:el-deficit-sangre-pais-188-522-unidadesEtltemid $=214$

13. Cruz Roja Dominicana (CRD). 2020. Available from: https://www. cruzroja.org.do/banco-de-sangre/

14. Charan J, Biswas T. How to calculate sample size for different study designs in medical research? Indian J Psychol Med. 2013;35:121-6. doi:10.4103/0253-7176.116232
15. Carneiro-Proietti $A B$, Sabino EC, Leao $S$, Salles NA, Loureiro $P$, Sarr $M$, et al. Human T-lymphotropic virus type 1 and type 2 seroprevalence, incidence, and residual transfusion risk among blood donors in Brazil during 2007-2009. AIDS Res Hum Retroviruses. 2012;28(10):1265-72. doi: 10.1089/aid.2011.0143

16. Pinto MT, Slavov SN, Valente VB, Ubiali E, Covas D, Kashima S et al. Evaluation of human T-lymphotropic virus prevalence/co-infection rates for a four-year period in a non-metropolitan blood center in Southeast Brazil. Rev Soc Bras Med Trop. 2016; 49(2): 232-6. doi: 10.1590/0037-8682-0282-2015

17. Morais MP, Gato CM, Maciel LA, Lalwani P, Costa C, Lalwani J et al. Prevalence of Human T-lymphotropic virus type 1 and 2 among blood donors in Manaus, Amazonas State. Brazil. Rev Inst Med Trop Sao Paulo. 2017;59:e80. doi: 10.1590/s1678-9946201759080

18. Mota-Miranda AC, Araújo SP, Dias JP, Duizit D, Kashima S, Covas D et al. HTLV-1 infection in blood donors from the Western Brazilian Amazon region: seroprevalence and molecular study of viral isolates. J Med Virol. 2008;80(11): 1966-71. doi: 10.1002/jmv.21300

19. Viana G, Nascimento M, Souza de Oliveira R, Dos Santos AC, Galvao $S$, da Silva MA. Seroprevalence of HTLV-1/2 among blood donors in the state of Maranhão, Brazil. Rev Bras Hematol Hemoter. 2014;36(1):50-3. doi: 10.5581/1516-8484.20140013

20. Reboucas K, Narici F, Santos Junior M, Neres N, Oliveira M et Souza C. Seroprevalence of transfusion-transmissible infectious diseases at a hemotherapy service located in southwest Bahia, Brazil. Hematol Transfus Cell Ther. 2019;41:324-8. doi: 10.1016/j. htct.2019.03.007

21. Pessoni $L$, De Aquino E et Alcantara K. Prevalence and trends in transfusion-transmissible infections among blood donors in Brazil from 2010 to 2016. Hematol Transfus Cell Ther. 2019; 41:310-31. doi: 10.1016/j.htct.2019.03.009

22. Ribeiro IP, Kozlowski AG, Dias de Matos MA, da Costa E Silva ÁM, Dos Santos Carneiro MA, Vicente ACP et al. HTLV-1 and -2 in a firsttime blood donor population in Northeastern Brazil: Prevalence, molecular characterization, and evidence of intrafamilial transmission. J Med Virol. 2018;90(10):1651-7. doi: 10.1002/jmv.25231.

23. Quispe NC, Feria EB, Santos-Fortuna E, Caterino-de-Araujo A. Confirming the presence of HTLV-1 infection and the absence of HTLV2 in blood donors from Arequipa, Peru. Rev Ins Med Trop São Pau. 2009;51(1):25-9. doi: 10.1590/S0036-46652009000100005

24. Macía C, Vargas S, Mora AM, Sarmiento AM, Pacheco R, Rosso F et al. Seroprevalence of human T-lymphotropic virus in blood bank donors at Fundación Valle del Lili, Cali, Colombia, 2008-2014. Biomedica. 2016:36(2):108-15. doi: 10.7705/biomedica.v36i0.2942

25. Cardona-Arias J, Velez-Quintero C, Calle-Gonzalez O, Florez-Duque $\mathrm{J}$ and Zapata JC. Seroprevalence of human T-lymphotropic virus HTLV and its associated factors in donors of a blood bank of Medellin-Colombia, 2014-2018. Plos One. 2019;14:e0221060. doi: 10.1371/journal.pone.0221060

26. Muñoz M, Carvalho S, Donado JH, Barco GE, Jaramillo S. [SHTLV-I/II seroprevalence in blood donors of Hospital Pablo Tobón Uribe Blood Bank during the period 2014-2015]. Biomedica. 2018;38(1):37-41. doi: 10.7705/biomedica.v38i0.3417. 
27. Bermúdez-Forero $M I_{1}$, Berrio-Pérez $M$, Herrera-Hernández $A M$, Rodríguez-Rodríguez MJ, García-Blanco S, Orjuela-Falla G et al. Prevalence of human T-cell lymphotropic virus I and II in Colombian blood donors, 2001-2014: Implications for transfusion safety. Biomedica. 2016;36(0):194-200. doi: 10.7705/biomedica.v36i0.2943.

28. San Martin H, Balanda M, Vergara N, Valenzuela MA, Cartier L, Ayala $\mathrm{S}$ et al. Human T-Lymphotropic Virus Type 1 and 2 Seroprevalence among first-time blood donors in Chile, 2011-2013. J Med Virol 2016: 88(6):1067-75. doi: 10.1002/jmv.24428

29. Borda MA, Svibel GR, Biglione MM, Berini CA. Hallazgo del virus linfotrópico T humano 1 (HTLV-1) subtipo Cosmopolita subgrupo Transcontinental (Aa) y del HTLV-2 subtipo b en donantes de sangre de Corrientes [Detection of Human T lymphotropic virus 1 (HTLV-1) Cosmopolitan subtype Transcontinental subgroup (Aa) and HTLV2 subtype $b$ in blood donors of Corrientes]. Rev Argent Microbiol. 2019;51(4):307-15. doi: 10.1016/j.ram.2018.10.004

30. Real Delor R, Moral A, Pérez L. Prevalencia del Virus Linfotrópico Humano en Donantes de Sangre del Hospital Nacional, Paraguay. Rev. Méd. La Paz. 2016;22(1):5-12. ISSN 1726-8958

31. De Rivera I, De Rivera E, Leda P. Prevalencia de HTLV-I/HTLV-II en donantes de Sangre de la Cruz Roja Hondureña, determinado por PCR. Rev Med Hond. 2004;72(1):3-9.

32. García $Z$, Cortés $X$, Torres $L$, Araúz $P$, Pacheco E, Taylor L. Detección de anticuerpos contra los virus linfotrópicos de células T tipo I/ II (HTLV I/ II) como medida de seguridad sanguínea en donantes de sangre en Costa Rica, mayo del 2002 a diciembre del 2004. Rev. costarric. cienc. méd. 2006;27(1-2):11-29. ISSN 0253-2948

33. Brady-West DC, Buchner LM. Retrospective audit of blood donation at a hospital-based blood centre. Implications for blood product supply and safety. West Indian Med J. 2000;49(3):226-8. PMID: 11076215

34. Vickers IE, Brathwaite AR, Levy M, Figueroa JP. Seroprevalence of sexually transmitted infections among accepted and deferred blood donors in Jamaica. West Indian Med. J 2006;55(2): 89-94. doi:10.1590/s0043-31442006000200005

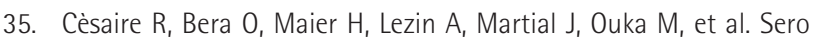
indeterminate patterns and seroconversions to human T-lymphotropic virus type I positivity in blood donors from Martinique, French West Indies. Transfusion. 1999;39(10): 1145-9. doi: 10.1046/j.1537-2995.1999.39101145.x

36. Rouet F, Foucher C, Rabier M, Gawronski I, Taverne D, Chancerel $B$, et al. Human T-lymphotropic virus type I among blood donors from Guadeloupe: donation, demographic, and biologic characteristics. Transfusion. 1999;39(6):639-44. doi: 10.1046/j.15372995.1999.39060639.x

37. Lubian A, Díaz H, Silva E, Pérez M, Cruz Sui Otto, De la Fuente JL, et al. Seroprevalencia de la infeccion por HTLV-1 en diferentes grupos de riesgo estudiados en Cuba. Rev Cubana Med. 1998;37(4):199204.

38. Martínez-Díaz H, Frye-Maldonado AC, Climent-Peris C, Vélez-Rosario R. Evaluation of serologic markers for transfusion transmitted infectious diseases for allogeneic blood donors in Puerto Rico. P R Health Sci J. 1997;16(3):255-8. PMID: 9431563
39. Filippone $\mathrm{C}$, Bassot $\mathrm{S}$, Betsem E, Tortevoye P, Guillotte M, Mercereau-Puijalon 0 et al. A new and frequent human T-cell leukemia virus indeterminate Western blot pattern: epidemiological determinants and PCR results in central African inhabitants. J. Clin. Microbiol. 2012:50,1663-72. doi: 10.1128/JCM.06540-11

40. Campos KR, Gonçalves MG, Costa NA, Caterino-de-Araujo A. Comparative performances of serologic and molecular assays for detecting human T lymphotropic virus type 1 and type 2 (HTLV-1 and HTLV-2) in patients infected with human immunodeficiency virus type 1 (HIV-1). Braz J Infect Dis. 2017;21(3):297-305. doi: 10.1016/j.bjid.2017.02.005

41. Cassar O, Gessain A. Serological and Molecular Methods to Study Epidemiological Aspects of Human T-Cell Lymphotropic Virus Type 1 Infection. Methods Mol Biol. 2017;1582:3-24. doi: 10.1007/9781-4939-6872-5_1 